\title{
EVALUASI POTENSI GAS RUMAH KACA BERDASARKAN SEKTOR KETENAGALISTRIKAN DAN INFRASTRUKUR PENYEDIAAN AIR MINUM DI KOTA BATAM
}

\author{
Yosef Adicita $^{1}$, Nurul Ulfah ${ }^{2}$, Sri Dewi Handayani ${ }^{3}$, I Wayan Koko Suryawan ${ }^{3}$ \\ ${ }^{1}$ Program Studi Teknik Lingkungan, Fakultas Teknik, Universitas Universal \\ 2Program Studi Teknik Mesin, Politeknik Negeri Batam \\ ${ }^{3}$ Program Studi Teknik Lingkungan, Fakultas Perencanaan Infrastruktur, Universitas Pertamina \\ Email: i.suryawan@universitaspertamina.ac.id
}

\begin{abstract}
Batam City is one of the biggest city in Indonesia. The economic development in Batam City is increasing, which is followed by the needs of the city. Electricity and water supply requirements are one of the essential aspects of the management of a city and sustainable development. Electricity consumption and water supply can contain carbon dioxide $\left(\mathrm{CO}_{2}\right)$ emissions. The purpose of this study was to estimated $\mathrm{CO}_{2}$ emissions in Batam City from electricity activity and water consumption. Calculation of carbon dioxide emissions from electricity consumption in Batam used an emission factor of 0.975 tons $\mathrm{CO}_{2} / \mathrm{MWh}$, while for water supply consumption used an emission factor of $0.51 \mathrm{kgCO} / \mathrm{m}^{3}$. Projections are carried out until 2030 in accordance with sustainable development goals. Based on electricity consumption, the highest contributor to emissions in 2014-2017 was the business sector with the highest value of 679,658 tons of $\mathrm{CO}_{2}$. Emissions of electricity consumption from the industrial sector fell from 567,904 tons of $\mathrm{CO}_{2}$ in 2014 to 510,630 tons of $\mathrm{CO}_{2}$ in 2017. The projected emissions that will emit emissions from the industrial sector will increase each year. Water consumption showed the highest emissions in the household sector at 28.461 tons of $\mathrm{CO}_{2}$ in 2017. Compared with the projected results on water supply, only $2.21 \%$ compared to the total electricity consumption emissions.
\end{abstract}

Keywords: $\mathrm{CO}_{2}$, Emission, Electricity, Water

\begin{abstract}
Abstrak
Kota Batam merupakan salah satu kota besar di Indonesia. Perkembangan ekonomi di Kota Batam semakin meningkat yang diikuti dengan kebutuhan kota tersebut. Kebutuhan listrik dan air bersih merupakan salah satu aspek esensial dalam menata kota dan pengembangan pembangunan berkelanjutan. Konsumsi listrik dan air bersih dapat mengandung emisi karbondioksida $\left(\mathrm{CO}_{2}\right)$. Tujuan penelitian ini adalah melakukan estimasi timbulan emisi $\mathrm{CO}_{2}$ di Kota Batam dari aktivitas ketenagalistrikan dan konsumsi air. Penghitungan emisi karbondioksida dari konsumsi listrik di Batam menggunakan faktor emisi sebesar 0,975 ton $\mathrm{CO}_{2} / \mathrm{MWh}$, sedangkan untuk konsumsi air bersih menggunakan faktor emisi $0,51 \mathrm{kgCO} 2 / \mathrm{m}^{3}$. Proyeksi dilakukan sampai tahun 2030 sesuai dengan tujuan pembangunan berkelanjutan. Berdasarkan konsumsi listrik, penyumbang emisi tertinggi tahun 2014-2017 adalah sektor usaha dengan nilai tertinggi 679.658 ton $\mathrm{CO}_{2}$. Emisi dari konsumsi listrik dari sektor industri mengalami penurunan dari 567.904 ton $\mathrm{CO}_{2}$ pada tahun 2014 menjadi 510.630 ton $\mathrm{CO}_{2}$ pada tahun 2017. Proyeksi emisi yang akan dikeluarkan dari sektor industri tersebut akan meningkat setiap tahunnya. Konsumsi air menunjukkan emisi tertinggi di sektor rumah tangga yaitu 28.461 ton $\mathrm{CO}_{2}$ pada tahun 2017. Dibandingkan hasil proyeksi penyediaan air bersih, hanya 2,21\% dari total emisi konsumsi listrik.
\end{abstract}

Kata Kunci : Air, $\mathrm{CO}_{2}$, Emisi, Listrik

\section{PENDAHULUAN}

Risiko yang ditimbulkan oleh perubahan iklim antropogenik sangat berbahaya, dan upaya yang terorganisir diperlukan untuk mengurangi dan memulihkan dampak tersebut (IPCC, 2014). Di seluruh dunia, terjadi peningkatan pada konsumsi air dan energi seiring bertambahnya jumlah penduduk. Pada sektor rumah tangga, konsumsi energi mencapai sekitar 40\% dari total konsumsi energi (Matos et al., 2019). Sebagian besar energi ini digunakan untuk penerangan, pemanas air, memasak dan pendingin udara (Duarte et al., 2010). Di Prancis, konsumsi energi dari penyediaan air minum disebabkan pemanas air dan menyumbangkan lebih dari 40\% dari total konsumsi energi dalam sektor domestik (Thiers \& Peuportier, 2012). Air dan energi tidak hanya saling terkait erat, tetapi juga sangat saling bergantung. Konsep energi-air yang muncul untuk mengeksploitasi interdependensi ini antara air dan energi, bersama dengan eksternalitasnya (Cai et al., 2016).

Kota Batam adalah kota pertumbuhan iklim bisnis yang sangat cepat di Indonesia. Banyak perkembangan di berbagai sektor, terutama sektor bisnis di Kota Batam setiap tahun menjadikannya sebagai tujuan bagi pencari kerja secara global (Siregar et al., 2018). Semakin tingginya iklim bisnis tersebut menjadikan Kota Batam mengalami 
Jurnal Matriks Teknik Sipil

DOI : https://dx.doi.org/10.20961/mateksi.v9i1.51089

ISSN: 2354-8630

E-ISSN: 2723-4223

Vol 9, No 1 (2021): Maret

pertumbuhan fasilitas dan hunian yang semakin padat. Meningkatnya jumlah fasilitas dan hunian masyarakat tersebut sejalan dengan meningkatnya kebutuhan energi listrik dan konsumsi air. Kebutuhan energi listrik dan air akan menghasilkan dampak lingkungan secara direct maupun indirect. Salah satu dampak indirect.adalah meningkatnya emisi karbon dioksida $\left(\mathrm{CO}_{2}\right)$ (Long et al., 2017).

Karbon dioksida adalah yang tidak memiliki warna, tidak menimbulkan berbau, dan cepat terbakar. Konsentrasi karbon dioksida ini di atmosfer diketahui telah naik di atas 320 ppm selama 40.000 tahun terakhir (Neftal et al., 1982). Beberapa penelitian menunjukkan bahwa karbon dioksida juga memberikan efek pada fisiologis tumbuhan (Sudiana, 2013). Tingkat karbon dioksida yang aman saat ini ditetapkan pada 5.000 ppm dengan paparan selama 8 jam dalam satu hari ataupun 40 jam dalam satu minggu (Robertson, 2006). Dampak yang ditimbulkan dari jejak karbon dioksida adalah potensi gas rumah kaca (GRK) atau perubahan iklim secara global (Ismail, 2020; Suryawan et al., 2021; Chairani et al., 2021). Penelitian ini dilakukan untuk memproyeksikan timbulan emisi $\mathrm{CO}_{2}$ dari sektor energi listrik dan konsumsi air di Kota Batam sampai pada tahun 2030. Pemilihan proyeksi sampai tahun 2030 ini dilakukan dengan menyesuaikan tujuan pembangunan berkelanjutan. Hasil proyeksi akan membantu dalam pelaksanaan upaya pencegahan dampak GRK dari konsumsi energi listrik dan konsumsi air dari berbagai sektor fasilitas masyarakat.

\section{METODE}

\section{Pengambilan Data}

Inventarisasi data sekunder digunakan dalam penelitian ini adalah data konsumsi listrik di Kota Batam dari tahun 2014 hingga tahun 2017. Sektor penggunaan energi listrik dibagi menjadi sektor sosial, rumah tangga, bisnis, pemerintahan, dan multiguna. Data konsumsi listrik didapatkan dari Kota Batam Dalam Angka 2017 dan Kota Batam Dalam Angka 2018.

Data konsumsi air didapat dari sumber yang sama dengan data konsumsi listrik di Kota Batam namun data yang digunakan adalah data pada tahun 2013 sampai tahun 2015 dan data tahun 2017. Sektor yang dikaji juga hampir sama dengan perbedaaan pada konsumsi air rumah tangga dan pemerintahan digabung menjadi satu serta terdapat fasilitas bandara dan pelabuhan tanpa sektor multi guna.

\section{Perhitungan Emisi $\mathrm{CO}_{2}$}

Perhitungan emisi CO2 dari konsumsi listrik mengikuti persamaan (1) dan data aktivitas manusia yang dimaksud adalah jumlah konsumsi listrik dan konsumsi air.

Emisi $\mathrm{CO}_{2}=$ Data aktivitas $\times$ Faktor Emisi

Faktor emisi dari konsumsi listrik di Kota Batam adalah 0,975 ton $\mathrm{CO}_{2} / \mathrm{MWh}$. Faktor emisi konsumsi listrik ini didapatkan dari Surat Kementerian Energi dan Sumber Daya Mineral, Direktorat Jenderal Ketenagalistrikan No. 157/29/DJL.4/2016. Faktor emisi dari konsumsi air adalah 0,51 $\mathrm{kgCO}_{2} / \mathrm{m}^{3}$ (Rahmawati et al., 2012)

\section{Proyeksi Emisi $\mathrm{CO}_{2}$}

Metode yang digunakan dalam memproyeksikan emisi $\mathrm{CO}_{2}$ adalah dengan menggunakan metode selisih kuadrat minimum. Metode selisih kuadrat minimum ini dapat dihitung dengan persamaan [2]. Metode ini digunakan untuk mendapatkan garis regresi linier yang berarti bahwa data perkembangan emisi $\mathrm{CO}_{2}$ tahun sebelumnya memiliki kecenderungan garis linier. Persamaan garis linier tersebut digunakan untuk menunjukkan peningkatan emisi $\mathrm{CO}_{2}$ secara teoritis meskipun perkembangan emisi tidak selalu bertambah secara linier.

$$
P n=a+(b t)
$$

Dimana :

$\mathrm{t} \quad=$ tambahan tahun terhitung dari tahun dasar

$\mathrm{a}=\frac{\left.\mid\left(\sum p\right)\left(\sum t^{2}\right)-\left(\sum t\right)\left(\sum p \cdot t\right)\right] .}{\left[n\left(\sum t^{2}\right)-\left(\sum t\right)^{2}\right]}$ 


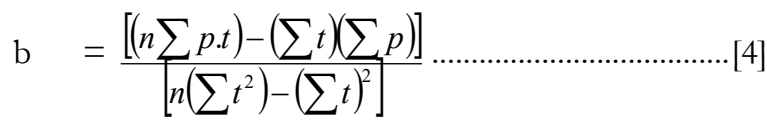

Perhitungan koefisien korelasi (r) dengan metode Least Square menggunakan persamaan [5].

$$
r=\frac{n\left(\sum x y\right)-\left(\sum x\right)\left(\sum y\right)}{\left\{n\left(\sum y^{2}\right)-\left(\sum y\right) \times\left[n\left(\sum x^{2}\right)-\left(\sum x\right)^{2}\right]\right\}^{\frac{1}{2}}} \ldots \ldots \ldots \ldots \ldots \ldots . . .[5]
$$

\section{HASIL DAN PEMBAHASAN}

Emisi $\mathrm{CO}_{2}$ dari Konsumsi Listrik

Perhitungan emisi $\mathrm{CO}_{2}$ didasarkan pada persamaan 1. Sektor yang mengonsumsi listrik dan menghasilkan emisi listrik tertinggi dari tahun 2014 sampai tahun 2017 adalah sektor bisnis. Penggunaan listrik pada sektor bisnis juga terlihat meningkat dari tahun 2014 hingga tahun 2017 (Tabel. 1). Berkembangnya bisnis di Kota Batam menyebabkan penggunaan energi listrik menjadi hal yang diutamakan demi kelancaran transaksi. Sektor selanjutnya yang mengalami peningkatan adalah sektor rumah tangga dan sosial. Pada sektor industri terlihat konsumsi listrik menurun dari tahun 2014 sampai tahun 2017. Timbulan emisi sektor industri eksisting sebesar 567.904 ton $\mathrm{CO}_{2}$ pada tahun 2014 dan menurun menjadi 510.630 ton $\mathrm{CO}_{2}$. Pada sektor pemerintahan terjadi peningkatan konsumsi listrik pada tahun 2015 dan 2016, dan mengalami penurunan pada tahun 2017. Menurut Hikmah dan Afriroda (2019), pada tahun dalam waktu tiga tahun terakhir yakni 67 perusahaan yang tutup pada tahun 2015, 67 perusahaan yang tutup pada tahun 2016, dan tercatat 25 perusahaan yang sudah tutup pada tahun 2017.

Tabel 1. Data konsumsi listrik dan hasil perhitungan emisi $\mathrm{CO}_{2}$ di Kota Batam

\begin{tabular}{|c|c|c|c|c|c|c|c|c|}
\hline \multirow{2}{*}{ Sektor } & \multicolumn{4}{|c|}{ Konsumsi Listrik (MWh) } & \multicolumn{4}{|c|}{ Emisi (ton $\mathrm{CO}_{2}$ ) } \\
\hline & 2014* & 2015* & 2016* & $2017 * *$ & 2014 & 2015 & 2016 & 2017 \\
\hline Sosial & 39.828 & 43.527 & 48.528 & 49.858 & 38.832 & 42.439 & 47.315 & 48.612 \\
\hline Rumah tangga & 582.735 & 603.858 & 637.035 & 620.517 & 568.167 & 588.762 & 621.109 & 605.004 \\
\hline Bisnis & 6288.21 & 651.500 & 697.085 & 684.538 & 613.100 & 635.213 & 679.658 & 667.425 \\
\hline Industri & 582.466 & 518.863 & 527.882 & 523.723 & 567.904 & 505.891 & 514.685 & 510.630 \\
\hline Pemerintahan & 47.611 & 50.302 & 53.900 & 48.577 & 46.421 & 49.044 & 52.553 & 47.363 \\
\hline Multiguna & 103.288 & 171.195 & 363.948 & 139.392 & 100.706 & 166.915 & 354.849 & 135.907 \\
\hline
\end{tabular}

\section{Proyeksi Emisi $\mathrm{CO}_{2}$ dari konsumsi Listrik}

Hasil proyeksi emisi $\mathrm{CO}_{2}$ dari konsumsi listrik di Kota Batam dapat dilihat pada Gambar 1. Dapat terlihat hasil proyeksi pada tahun 2019 sampai tahun 2030 emisi $\mathrm{CO}_{2}$ dari penggunaan listrik semakin meningkat. Peningkatan terjadi sebesar 20\%, dari 2,3 juta ton $\mathrm{CO}_{2}$ pada tahun 2019 menjadi 2,9 juta ton $\mathrm{CO}_{2}$ pada tahun 2030. Jika dihitung dengan persamaan Rahman et al (2017), yang menyebutkan spesies Nypa fruticans mampu menyerap 80,02-ton $\mathrm{CO}_{2} /$ hektar selama waktu sehari. Pada tahun 2019 setidaknya terdapat 79 hektar tanaman Nypa fruticans dan pada tahun 2030 setidaknya luas lahan menjadi 99 hektar. Hasil proyeksi pada tahun dari tahun 2019-2030 terlihat bahwa setiap sektor mengalami peningkatan. Akan tetapi, pada sektor industri mengalami penurunan yang drastis sedangkan pada sektor multiguna terjadi peningkatan yang cukup pesat. Pada sektor sosial, bisnis dan rumah tangga mengalami peningkatan yang tidak signifikan. 


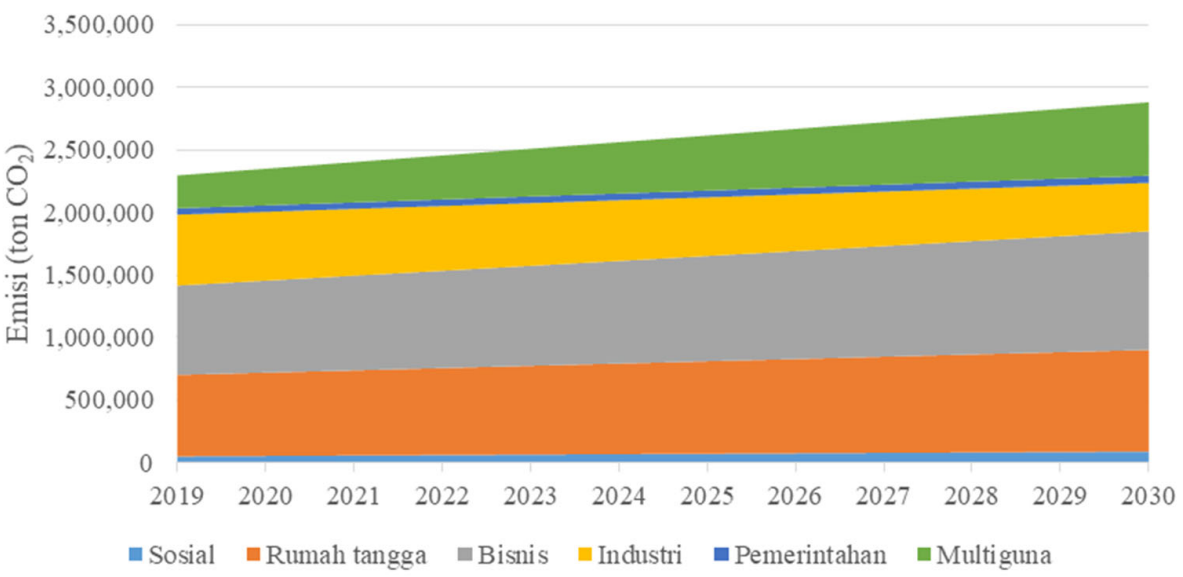

Gambar 1. Proyeksi emisi $\mathrm{CO}_{2}$ dari konsumsi kistrik di Kota Batam dari tahun 2019-2030 (ton $\mathrm{CO}_{2}$ )

Gambar 2 memperlihatkan komposisi sektor terbesar penyumbangkan emisi $\mathrm{CO}_{2}$ yaitu sektor bisnis sebesar $33 \%$ kemudian disusul sektor rumah tangga diposisi kedua yaitu 28\%. Arisandi dan Pradana (Arisandi, \& Pradana, 2018) menyebutkan Kota Batam saat ini telah beralih fungsi dari kota industri menjadi kota pariwisata. Hal ini mendukung bahwa potensi emisi dari kegiatan industri akan menurun dan emisi dari sektor bisnis akan meningkat. Meningkatnya kegiatan bisnis di Kota Batam sejalan dengan tujuan terkini Kota Batam menjadi kota pariwisata. Meningkatnya kegiatan wisata juga mempengaruhi meningkatnya kebutuhan operasional bisnis seperti kebutuhan listrik dan penyediaan air bersih.

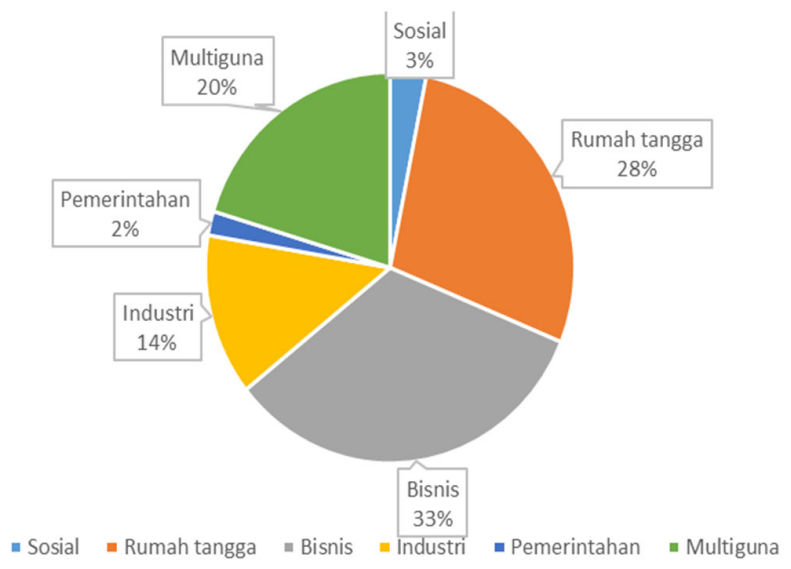

Gambar 2. Persentase sektor penyumbang emisi $\mathrm{CO}_{2}$ dari konsumsi listrik di Kota Batam berdasarkan hasil proyeksi pada tahun 2030 
Tabel 2. Data konsumsi air dan hasil perhitungan emisi $\mathrm{CO}_{2}$ di Kota Batam

\begin{tabular}{|c|c|c|c|c|c|c|c|c|}
\hline \multirow{2}{*}{ Sektor } & \multicolumn{4}{|c|}{ Konsumsi Air $\left(\mathrm{m}^{3}\right)$} & \multicolumn{4}{|c|}{ Emisi (ton $\mathrm{CO}_{2}$ ) } \\
\hline & $2013 *$ & $2014 *$ & $2015 *$ & $2017 *$ & 2013 & 2014 & 2015 & 2017 \\
\hline Sosial & 2.820 .164 & 3.238 .163 & 3.538 .360 & 4.859 .401 & 1.438 & 1.651 & 1.805 & 2.478 \\
\hline $\begin{array}{l}\text { Rumah tangga dan } \\
\text { pemerintahan }\end{array}$ & 48.300 .535 & 52.015 .844 & 54.134 .492 & 55.805 .457 & 24.633 & 26.528 & 27.609 & 28.461 \\
\hline Bisnis & 9.582 .204 & 10.437 .758 & 10.861 .748 & 11.880 .498 & 4.887 & 5.323 & 5.539 & 6.059 \\
\hline Industri & 5.678 .364 & 5.818 .944 & 6.461 .650 & 5.823 .348 & 2.896 & 2.968 & 3.295 & 2.970 \\
\hline $\begin{array}{l}\text { Pelabuhan / Ban- } \\
\text { dara }\end{array}$ & 290.455 & 332.412 & 322.790 & 252.680 & 148 & 170 & 165 & 129 \\
\hline
\end{tabular}

\section{Emisi $\mathrm{CO}_{2}$ dari Konsumsi Air}

Konsumsi air menjadi salah satu kegiatan yang berpotensi menyumbangkan emisi. Meningkatnya kebutuhan penduduk menyebabkan pasokan air suatu kota juga meningkat. Hal ini dapat dilihat pada Tabel 2 bahwa konsumsi air di Kota Batam sangat didominasi oleh kegiatan rumah tangga dan pemerintahan. Persentase konsumsi air pada sektor rumah tangga mencapai 71-72\% pada tahun 2013 hingga tahun 2017. Pada beberapa sektor konsumsi air cenderung meningkat diantaranya sektor sosial, bisnis, dan industri. Konsumsi air pada sektor pelabuhan dan bandara cenderung fluktuatif.

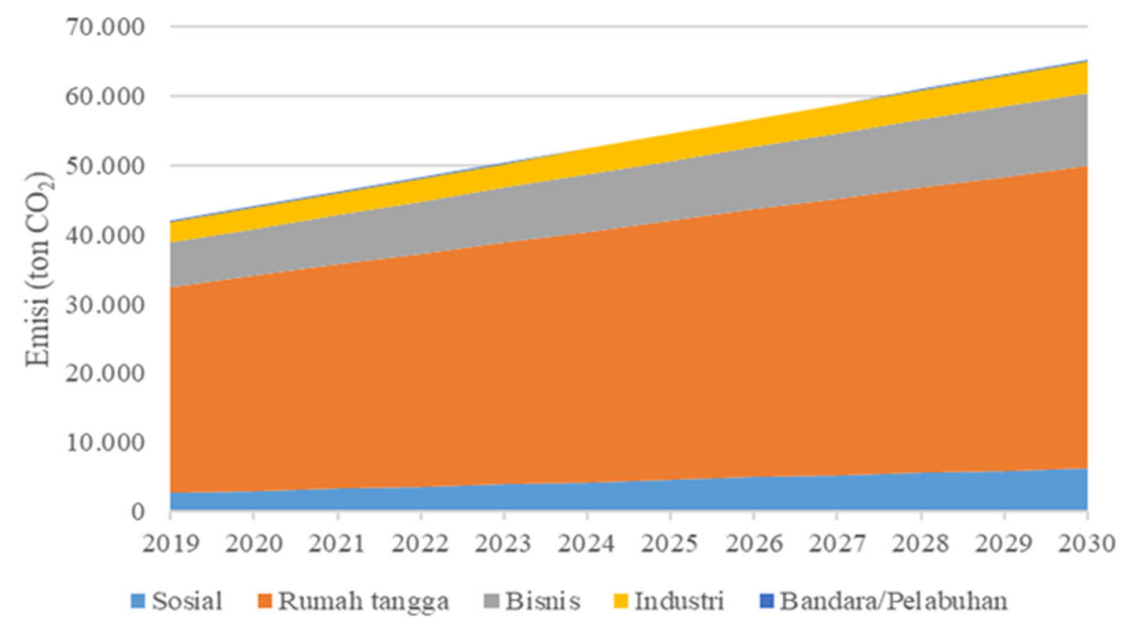

Gambar 3. Proyeksi emisi $\mathrm{CO}_{2}$ dari konsumsi air di Kota Batam dari Tahun 2019-2030 (ton $\mathrm{CO}_{2}$ ) 


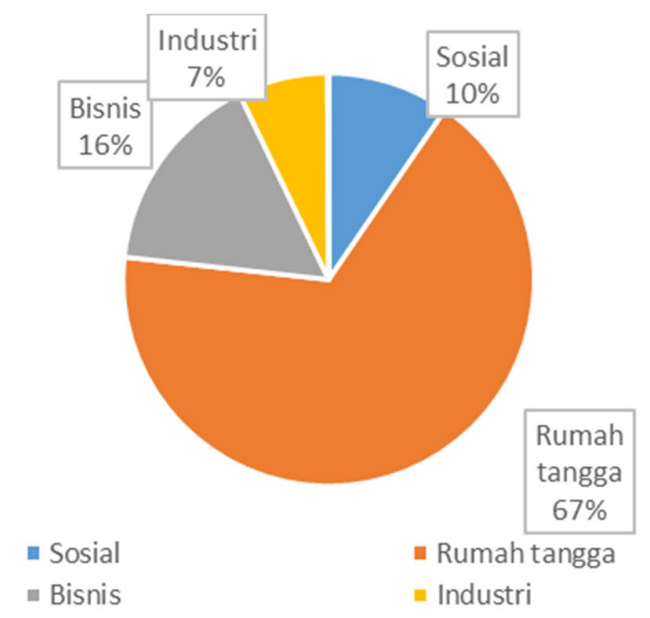

Gambar 4. Persentase sektor penyumbang emisi $\mathrm{CO}_{2}$ dari konsumsi air di Kota Batam berdasarkan hasil proyeksi pada tahun 2030.

\section{Proyeksi Emisi $\mathrm{CO}_{2}$ dari konsumsi Air}

Emisi yang dihasilkan dari proyeksi konsumsi air di Kota Batam cenderung meningkat drastis dibandingkan (Gambar 2) dengan konsumsi listrik (Gambar 1). Pentingnya air sebagai sumber kehidupan menjadikan produksi air bersih menjadi hal utama yang harus dipenuhi terutama kepada masyarakat. Meningkatnya populasi cenderung menempatkan sarana penyediaan air bersih menjadi hal utama yang harus diberikan ke masyarakat.

Penyediaan air bersih dapat memberikan emisi $\mathrm{CO}_{2}$ secara tidak langsung. Emisi $\mathrm{CO}_{2}$ yang dikeluarkan oleh kegitan ini adalah pemompaan, kebocoran, dan adanya timbulan air limbah (Apritama et., 2020). Selain itu proses pengolahan air baku menjadi air minum juga merupakan salah satu kegitan yang berpotensi menimbulkan dampak emisi $\mathrm{CO}_{2}$.

Tabel 3. Perbandingan emisi $\mathrm{CO}_{2}$ dari konsumsi listrik dan penyediaan air di Kota Batam

\begin{tabular}{lll}
\hline Tahun & $\begin{array}{l}\text { \% Emisi } \\
\text { Konsumsi Listrik }\end{array}$ & $\begin{array}{l}\text { \% Emisi } \\
\text { Penyediaan Air }\end{array}$ \\
\hline 2019 & 98,20 & 1,80 \\
2020 & 98,16 & 1,84 \\
2021 & 98,11 & 1,89 \\
2022 & 98,07 & 1,93 \\
2023 & 98,03 & 1,97 \\
2024 & 97,99 & 2,01 \\
2025 & 97,95 & 2,05 \\
2026 & 97,92 & 2,08 \\
2027 & 97,88 & 2,12 \\
2028 & 97,85 & 2,15 \\
2029 & 97,82 & 2,18 \\
2030 & 97,79 & 2,21 \\
\hline
\end{tabular}

Proyeksi pada tahun 2030 menyebutkan total emisi dari konsumsi air di Kota Batam dapat mencapai 65.188 ton $\mathrm{CO}_{2}$. Jika dibandingkan dengan konsumsi listrik, konsumsi air menyumbangkan $10 \%$ dari total emisi $\mathrm{CO}_{2}$ dari jumlah total konsumsi listrik dan air. Di Amerika Serikat, sekitar 4\% dari total konsumsi energi nasional digunakan untuk mengolah air minum dan air limbah (CSR, 2013). (Gambar 4) memperlihatkan bahwa sektor rumah tangga menyumbangkan emisi terbesar sekaligus membutuhkan penyediaan air sebesar $67 \%$ dari total jumlah produksi air. Kemudian pada sektor industri, sosial, dan bisnis masing -masing menyumbangkan 7\%, 10\%, dan $16 \% \mathrm{emisi}^{\mathrm{CO}_{2}}$ dari konsumsi air. 
Jurnal Matriks Teknik Sipil

DOI : https://dx.doi.org/10.20961/mateksi.v9i1.51089

ISSN: 2354-8630

E-ISSN: 2723-4223

Vol 9, No 1 (2021): Maret

Perbandingan emisi $\mathrm{CO}_{2}$ dari hasil proyeksi menunjukkan tidak terjadi peningkatan yang signifikan. Terlihat emisi dari penyediaan air meningkat dari 1,80\% dari tahun 2019 menjadi 2,21\% pada tahun 2030. Walaupun emisi dari penyediaan air rendah tingkat konsumsi air dapat menghasilkan air limbah yang dapat menghasilkan $\mathrm{CO}_{2}$. Emisi dari pengolahan air limbah dapat terjadi dari mekanisme degradasi bahan organik secara aerobik, anaerobik, maupun anoksik.

\section{SIMPULAN}

Emisi dari konsumsi listrik dan penyediaan air di Kota Batam mempunyai nilai yang berbeda untuk masing-masing sektor. Pada konsumsi listrik, sektor yang menghasilkan emisi terbanyak adalah sektor industri, sedangkan untuk penyediaan air, penyumbang emisi tertinggi adalah sektor rumah tangga. Emisi pada sektor industri cenderung menurun dari tahun 2014 ke tahun 2017. Berdasarkan proyeksi emisi, konsumsi listrik menghasilkan 98,79\% emisi pada tahun 2030 dan penyediaan air yakni menghasilkan 2,21\% emisi pada tahun 2030 .

\section{REFERENSI}

Apritama, M. R., Suryawan, I. W. K., \& Adicita, Y., 2020,. “Analisis Hidrolis dan Jejak Karbon Jaringan Distribusi Air Bersih di Pulau Kecil Padat Penduduk (Pulau Lengkang Kecil, Kota Batam)”. Jurnal Teknologi Lingkungan, 21(2), 227-235.

Arisandi, D., \& Pradana, M. N. R., 2018,. "Pengaruh Penggunaan Social Media Terhadap Brand Awareness Pada Objek Wisata Di Kota Batam", Jurnal Riset Manajemen \& Bisnis Dewantara, JMD, 1(2), 109-116.

Badan Pusat Statistik Kota Batam., 2017, "Kota Batam Dalam Angka 2017”, BPS Kota Batam. Batam.

Badan Pusat Statistik Kota Batam., 2018, "Kota Batam Dalam Angka 2018”, BPS Kota Batam. Batam.

Cai, J., Yin, H., \& Varis, O., 2016, "Impacts of industrial transition on water use intensity and energy-related carbon intensity in China: A spatio-temporal analysis during 2003-2012. Applied energy, 183, 1112-1122.

Chairani, R., Adinda, A. R., Fillipi, D., Jatmoko, N., Suryawan, I. W. K., 2021, "Environmental Impact Analysis in The Cement Industry with Life Cycle Assessment Approach". JTERA (Jurnal Teknologi Rekayasa), 6 (1)

CRS (2013) Energy-water nexus: the water sector's energy use. Congressional Research Service (CRS) 7-5700, CRS, Washington, D

Duarte, A. N. A. B. E. L. A., Coelho, D. U. L. C. E., \& Tomás, N. U. N. O. (2010, May). Photovoltaic integration in buildings. A case study in Portugal. In Proceedings of the International Conference on Renewable Energies Sources (pp. 119-123).

Hikmah, H., \& Afridola, S., 2019, “Analisis Penilaian Financial Distress Menggunakan Model Altman (Z-Score) Perusahaan Manufaktur", Jurnal Niara, 11(2), 195-202.

IPCC, 2014, "Synthesis report. contribution of working groups i, ii and iii to the fifth assessment report of the intergovernmental panelon climate change," IPCC, Tech. Rep., 2014.

Ismail, A., 2020, "Potensi penurunan emisi gas rumah kaca (GRK) dalam kegiatan belajar di rumah secara on-line: analisis jejak karbon (carbon footprint analysis)". Jukung (Jurnal Teknik Lingkungan), 6(2).

Kementerian Energi dan Sumber Daya Mineral, Direktorat Jenderal Ketenagalistrikan No. 157/29/DJL.4/2016 tentang Faktor Emisi Gas Rumah Kaca Sistem Interkoneksi Tahun 2014.

Long, Y., Yoshida, Y., \& Dong, L., 2017, "Exploring the indirect household carbon emissions by source: Analysis on 49 Japanese cities", Journal of Cleaner Production, 167, 571-581.

Matos, C., Bentes, I., Pereira, S., Faria, D., \& Briga-Sa, A., 2019, "Energy consumption, $\mathrm{CO}_{2}$ emissions and costs related to baths water consumption depending on the temperature and the use of flow reducing valves", Science of The Total Environment, 646, 280-289.

Neftal, A., Oeschger, H., Schwander, J.,Steuffer, B. and Zumbrunn, R.,1982, "Ice Core Sample Measurement Gives Atmospheric CO2 Content over the Past 40,000 yr", Nature.295:220-223.

Rahman, R., Effendi, H., \& Rusmana, I., 2017, "Estimasi Stok dan Serapan Karbon pada Mangrove di Sungai Tallo, Makassar", Jurnal Ilmu Kehutanan, 11(1), 19-28.

Rahmawati, L. A., Haryono, E., \& Fandeli, C., 2012, "Studi Optimalisasi Sequestrasi Karbon Dioksida (CO2) Berbasis Rumah Tangga", Majalah Geografi Indonesia, 26(1), 59-79.

Robertson, D. S., 2006, "Health Effects of Increase in Concentration of Carbon Dioxide in the Atmosphere", Current Science.90(12):25 June 2006.

Siregar, A. H., Syahputra, D., Putra, D. A., \& Wicaksono, B., 2018, "Policy Evaluation of Security System Based on Security Camera Technology in Batam City", In IOP Conference Series, Earth and Environmental Science (Vol. 175, No. 1, p. 012105), IOP Publishing. 
Jurnal Matriks Teknik Sipil

DOI : https://dx.doi.org/10.20961/mateksi.v9i1.51089

ISSN: $2354-8630$

E-ISSN: 2723-4223

Vol 9, No 1 (2021): Maret

Sudiana, I. K., 2013, "Dampak adaptasi lingkungan terhadap perubahan fisiologis". In Prosiding Seminar Nasional MIPA.

Suryawan, I. W. K., Rahman, A., Septiariva, I. Y., Suhardono, S., \& Wijaya, I. M. W., 2021, "Life Cycle Assessment Of Solid Waste Generation During And Before Pandemic Of Covid-19 In Bali Province", Journal Of Sustainability Science And Management, 16(1), 11-21.

Thiers, S., \& Peuportier, B., 2012, "Energy and environmental assessment of two high energy performance residential buildings". Building and Environment, 51, 276-284 